\title{
PALMD Gene
}

National Cancer Institute

\section{Source}

National Cancer Institute. PALMD Gene. NCI Thesaurus. Code C105937.

This gene may play a role in plasma membrane dynamics. 